\title{
Scenarios of water quality management in watershed with distributed spatio-temporal simulation
}

\section{Cenários de gestão de qualidade da água em bacia hidrográfica com simulação espaço-temporal distribuída}

\author{
Kelen Mannes Knaesel ${ }^{1}$ (D), Adilson Pinheiro ${ }^{1}$ (D), Pedro Thiago Venzon ${ }^{1}$ (D) \& Vander Kaufmann ${ }^{1}$ (D) \\ ${ }^{1}$ Fundação Universidade Regional de Blumenau, Blumenau, SC, Brasil \\ E-mails: kmannes1@gmail.com (KMK),pinheiro@furb.br (AP), pedro.thiago@hotmail.com (PTV), vanderkaufmann@gmail.com (VK)
}

Received: January 31, 2019 - Revised: December 12, 2019 - Accepted: January 29, 2020

\begin{abstract}
The implementation of National Water Resources Policy instruments depends on detailed information in space and time, on a large scale, within the river basin. This research aims to evaluate scenarios to support water quality management in watershed by modelling with spatio-temporal discretization distributed in a small spatial dimension. The SWAT hydrological model was applied in the Itajai river basin. This hydrographic basin with $15,000 \mathrm{~km}^{2}$ was discretized in 2,103 hydrological response units (HRUs). The model input data for each HRU were fed in, from the quantitative and qualitative aspects. The time series of water quality was obtained in non-systematic monitoring from different sources, such as water supply companies and potential polluting companies, among others. The model calibration and validation were performed, presenting adequate results for both the quantitative and qualitative processes. The scenarios corresponding to current and evolutionary situations of pollutant contribution for four water quality parameters (biochemical oxygen demand, total phosphorus, total nitrogen and thermotolerant coliforms) were analysed. The results are expressed as the mean, median, non-exponential frequency of $80 \%$ and reference flow, discussing the statistical index that best represents the pollutant concentrations in the bodies of water. The simulations show that the measures proposed for the water quality management of the basin promote a significant reduction in pollutant concentrations in comparison to the critical scenario. According to the results, it can be affirmed that the discretization of the basin in small contribution areas generates greater results precision of the model. The daily and distributed data in the basin provide localized information, according to the basin ortho coding, supporting the decision in order to support the management of water resources, contributing to the implementation process of the framework of surface water courses in the basin, as well as serving as a generic model for other purposes.
\end{abstract}

Keywords: Water resources management; Framework of water courses; Hydrological modelling; SWAT.

\section{RESUMO}

A implementação dos instrumentos da Política Nacional de Recursos Hídricos depende de informações detalhadas no espaço e no tempo, em grande escala, no âmbito da bacia hidrográfica. Este trabalho tem como objetivo avaliar cenários para suporte à gestão de qualidade da água em bacias hidrográficas por modelagem com discretização espaço-temporal distribuída, em pequena dimensão espacial. Foi aplicado o modelo hidrológico SWAT na bacia do rio Itajaí. A bacia hidrográfica de $15000 \mathrm{~km}^{2}$ foi discretizada em 2103 unidade de resposta hidrológica (HRU). Para cada foram alimentados os dados de entrada do modelo, dos aspectos quantitativos e qualitativos. As séries temporais de qualidade das águas foram obtidas em monitoramentos não sistemáticos, provenientes de diferentes fontes, como empresas de abastecimento de águas, empresas potencialmente poluidoras, entre outras. A calibração e validação do modelo foram realizadas, apresentando resultados adequados tanto para o processo quantitativo como para o processo qualitativo. Foram analisados os cenários da situação atual e evolutivos de contribuição de poluentes, para quatro parâmetros de qualidade da água (demanda bioquímica de oxigênio, fósforo total, nitrogênio total e coliformes termotolerantes). Os resultados são expressos pela concentração média, mediana, frequência de não excendência de $80 \%$ e vazão de referência, discutindo o índice estatístico que melhor representa as concentrações de poluentes nos corpos hídricos. As simulações mostraram que as medidas propostas para a gestão de qualidade da água da bacia, promovem significativa redução das concentrações dos poluentes em comparação ao cenário 
crítico. Pela análise dos resultados pode-se afirmar que a discretização da bacia em pequenas áreas de contribuição geram maior precisão dos resultados do modelo e os dados diários e distribuídos na bacia fornecem informações localizadas, de acordo com a ortocodificação da bacia, dando suporte à tomada de decisão de modo a apoiar a gestão de recursos hídricos, contribuindo com o processo de implantação do enquadramento dos corpos de águas superficiais da bacia, assim como servir de modelo genérico para outras finalidades.

Palavras-chave: Gestão de recursos hídricos; Enquadramento de corpos de água; Modelagem hidrológica; SWAT.

\section{INTRODUCTION}

Water quality and availability depend on actions taken jointly by society and the public authority, which, through planning and management of water resources, must ensure conditions compatible with their intended use (Agência Nacional de Águas, 2013). For this purpose, the National Water Resources Policy (NWRP) instituted the instruments of water resources management through law No. 9433/1997, which provides for public debate on water preservation and conservation and its rational use, aiming at sustainability and ecosystems balance (Brasil, 1997). Among the instruments for water resources management are water resources plans (WRP) and the classification of water courses according to their prevailing uses (Brasil, 1997).

For the implementation of NWRP instruments, mapping current water use, quality and available quantity, as well as existing conflicts, is required. These data facilitate understanding the use of water resources, establishing future scenarios and executing the planning, according to the classification of water courses, which can be established from these indicators (Agência Nacional de Águas, 2013).

Simulation models of quantitative and qualitative processes are used to diagnose and predict the water quality. Their application allows generating future scenarios, determining polluting sources and assisting decision-making for water resource management (Batista \& Cabral, 2017). Bitencourt (2018) reported that most works for framing water courses in Brazil use one-dimensional models of steady states. One-dimensional models, such as QUAL2E, QUAL2K and QUAL-UFMG, are used to generate current and future water quality scenarios for water courses (Lima et al., 2018; Fantin et al., 2017; Calmon et al., 2016; Salla et al., 2013; Teodoro et al., 2013; Silva, 2016; Noh et al., 2015; Babbar, 2014; Wu \& Fan, 2017; Korf et al., 2017). However, it should be considered that different flow rates influence water quality behaviour, as demonstrated by Brites (2010), Ferreira et al. (2016) and Calmon et al. (2016). The one-dimensional models used are constant over time.

The SWAT (Soil \& Water Assessment Tool) model was used in this study. The SWAT is an integrated, dynamic and distributed GIS model with a physical basis, allowing representation of the local reality regarding soil type, topography and land use (Neitsch et al., 2011). This model does not need monitoring at strategic points (Neitsch et al., 2011), becoming an ally in predicting water quality from data obtained in non-systematic monitoring (Girardi, 2019), without large investments. SWAT is a widely used model to support decision-making in water resource management, modelling water quality through pollutant removal efficiency (Seo et al., 2017; Bressiani et al. 2015). Venzon et al. (2018) applied the SWAT model in the Itajai river basin, discretizing the spatial dimension in small contribution areas.

For application of the SWAT model, information is required at three spatial scale levels: basin, sub-basins and hydrological response units (HRUs). The flow is calculated for each HRU, being programmed to obtain the flows in the sub-basins and finally, of the hydrographic basin as a whole. Thus, adoption of the small HRUs can provide a better physical simulation of the water balance and increase the precision of flow estimates and concentrations in the basin (Neitsch et al., 2011), necessary for water resources management. In addition, the model allows the user to define management practices occurring in all HRUs, with the capacity to represent space-time heterogeneity with distributed spatial discretization (Baffaut et al., 2015). In light of the above, this study aims to evaluate scenarios to support water quality management in watersheds by modelling with distributed spatio-temporal discretization, to aid decision-making during the process of framing water courses into classes according to the prevailing uses.

\section{MATERIALS AND METHODS}

\section{Study area}

The study area is the Itajai River watershed, the largest of the Atlantic slope, located in Santa Catarina state, with $15,000 \mathrm{~km}^{2}$, shown in Figure 1. The basin has a population of $1,240,000$ inhabitants, including an urban population of around $1,040,000$ inhabitants. The area is distributed in 49 municipalities; Blumenau city is the region's main economic centre (Antunes \& Constante, 2016).

The main stretches, with regard to basin degradation, are found after the confluence of the Itajai do Oeste River and the Itajai do Sul River, from the cities of Rio do Sul, Blumenau, Gaspar, Brusque and Itajai. The largest urban centres in the basin are concentrated in this area, with a very diversified industrial park (textiles, fishing, metal-mechanics, paper, pulp, tannery, starch extraction and vegetable oil extraction), responsible for the majority of releases of pollution loads into the water courses. In addition to industrial waste disposal, there are also residues resulting from swine farming, rice cultivation and domestic sewage, all sources of environmental degradation (Antunes \& Constante, 2016).

The study area was subdivided into 2,103 HRUs (Figure 1). The division by HRUs resulted in small stretches, with average areas of 715 ha, representing the basin ortho coding. This means that in each of the 2,103 HRUs, quantitative and qualitative data on water courses can be generated. 

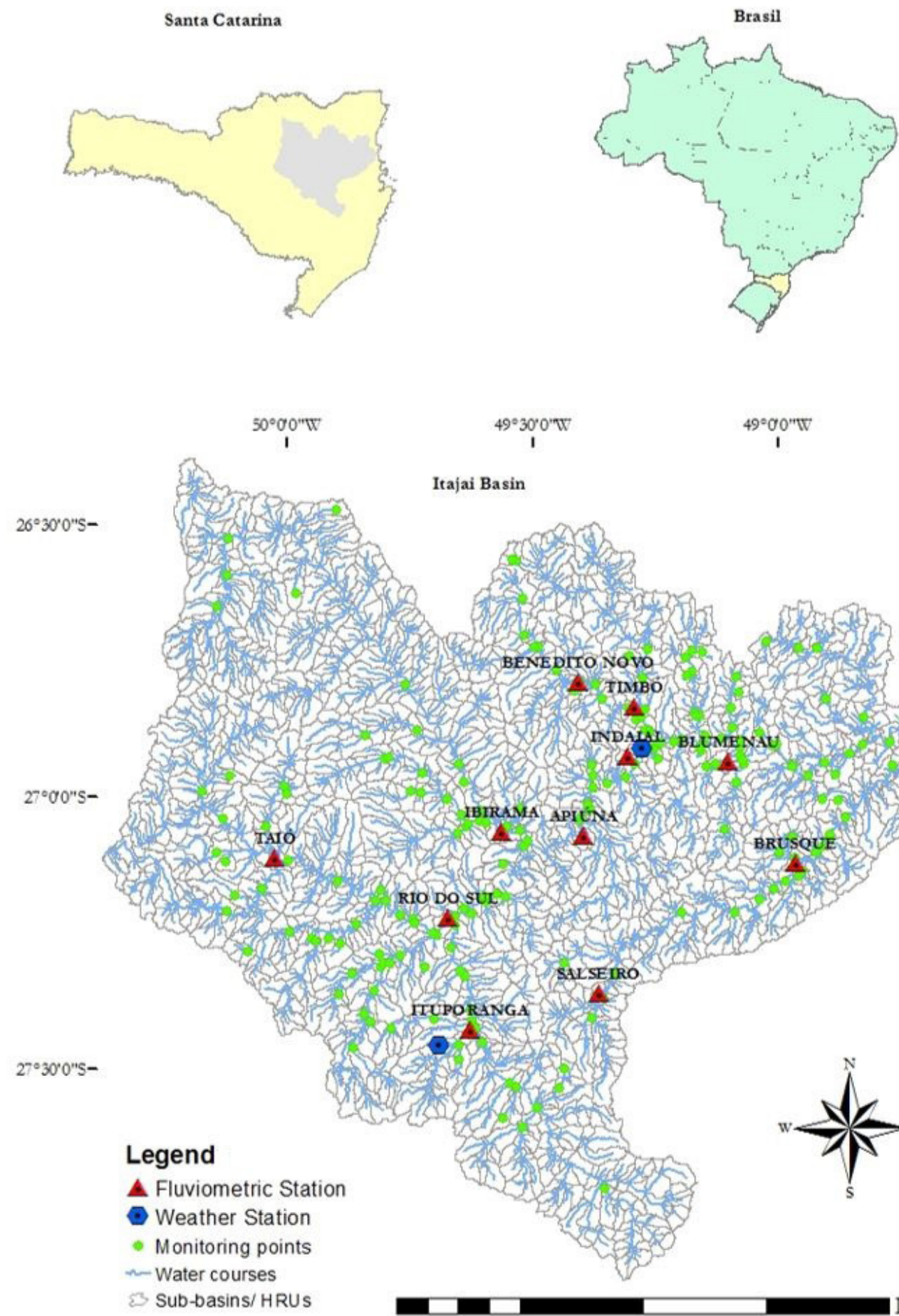

$28^{\circ} 00^{\prime \prime}-$

\section{Legend \\ Aluviometric Station \\ - Monitoring points \\ Water courses \\ -basins/ HRUs}

Figure 1. Study area, HRUs discretization and fluviometric stations, meteorological and monitoring points of domestic and industrial sewage.

\section{Hydrological model}

Application of the SWAT model to the adopted spatial discretization scale requires compatible input data. The Digital Terrain Model (DTM) and hydrography were obtained in Santa Catarina (2017a). The DTM was created by aerial survey, between
2010 and 2013, with a final resolution of 1.0 meter and allows contour lines extraction with a 5-meter equidistance.

The pedological data were obtained in Santa Catarina (2017b). The predominant soil in the Itajai basin is cambisol $(45.40 \%)$, followed by littoral soils $(25.87 \%)$ and red-yellow argisol $(20.34 \%)$. Low humic glei $(6.38 \%)$, water $(1.04 \%)$, structured 
bruna earth $(0.94 \%)$ and marine quartz sands $(0.03 \%)$ make up the smallest portion of the basin.

The classification map of land use and occupation (Figure 2) was elaborated in the Atlantic Forest Project in Santa Catarina (Geoambiente Sensoriamento Remoto Ltda, 2008). The Itajai basin is composed mainly of native forest $(57.61 \%)$, followed by pastures $(20.76 \%)$, diverse agriculture $(13.44 \%)$, eucalyptus $(5.12 \%)$, urban area $(2.23 \%)$, water $(0.55 \%)$ initial forest $(0.24 \%)$ and exposed soil $(0.04 \%)$.

Data from 14 rainfall stations contained in ANA (Agência Nacional de Águas, 2018) and from 3 other stations monitored in the Concordia river basin were used to calculate precipitation. For the quantitative (flow) model calibration, 11 fluviometric stations in the basin were used (Figure 1). As the data series available in ANA (Agência Nacional de Águas, 2018) was not included for the period, data available in Venzon et al. (2018) were used. The temperature, solar radiation, wind speed and relative air humidity were extracted from Instituto Nacional De Meteorologia (2018) from two monitoring stations, Indaial and Ituporanga (Santa Catarina state). Daily data from 1 January 2002 to 12 December 2017 were considered in the modelling.

\section{Water quality model}

Monitoring the water quality in a watershed like that of the Itajai river, with $15,000 \mathrm{~km}^{2}$ and $900 \mathrm{~km}$ of main rivers, is a great challenge implying high costs for equipment, analysis and qualified professionals, which are not available. Therefore, in order to launch the industrial loads, it was decided to use data generated by companies that use water, and that have water abstraction or discharge into the river basin (Figure 1). This information is required by the regulatory agencies and, to date, has not been used for water resources management (Pinheiro et al. 2017). To this end, the Itajai River Basin Framework Enhancement Program (IRBFEP) was created. In this program, an integration system was developed to provide the water quality data of the Itajai river basin.

Data from household expulsions, referring to the 49 municipalities that compose the Itajai basin, were calculated according to population by municipality, as measured in the Demographic Census 2010 (Instituto Brasileiro de Geografia e Estatística, 2017), and the physical-chemical characteristics of the sanitation sewers described in Von Sperling (2005).

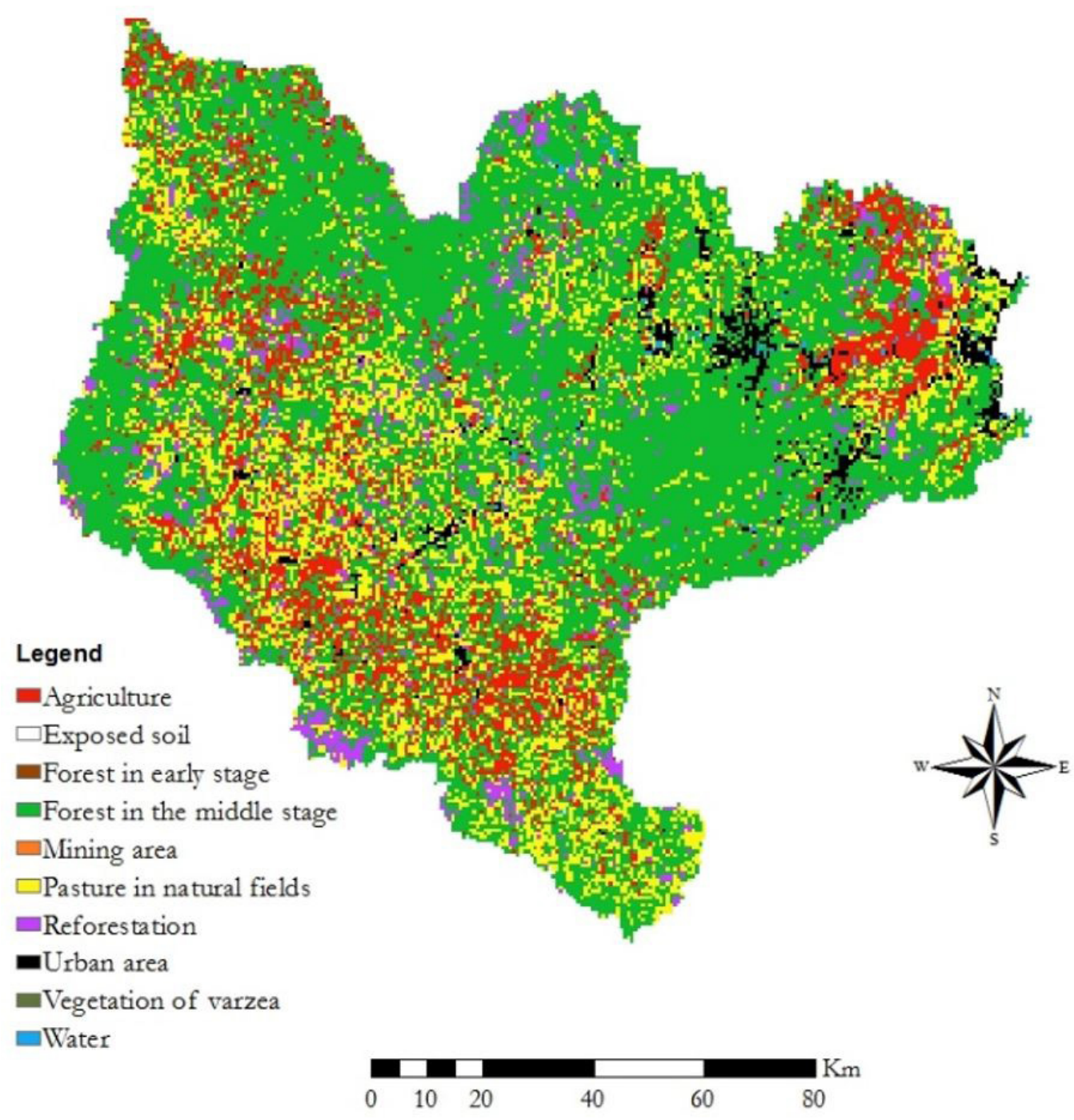

Figure 2. Classification map of land use and occupation. Source: Geoambiente Sensoriamento Remoto Ltda, 2008. 
To obtain household expulsions loads, population projections were carried out for the years 2010 to 2017, by geometric projection, for each municipality belonging to the Itajai basin. After the population of each municipality was obtained, water quality parameters were calculated by per capita contribution, as shown in Table 1 . The flow was generated from monthly water consumption data by municipality found in SNIS (Sistema Nacional de Informações sobre Saneamento, 2017). With the monthly consumption data, daily per capita consumption was obtained, which, multiplied by the population, provided the daily flow of each municipality in the Itajai basin.

\section{Model calibration and validation}

Model calibration and validation were performed manually and iteratively until adequate values representative of the basin's physical situation were reached. For model heating, it was decided to use the simulation covering 8 prior years to the period evaluated, that is, from 2002 to 2010. According to Mello et al. (2008), in the initial simulation phase, there are great uncertainties due to unfamiliarity with the initial conditions, justifying the use of a heating period, so that when the simulation begins, the variables are free of the influence of the initial conditions. The calibration and validation periods used were, respectively, 4 years (2010-2014) and 2 years (2015-2016). The Nash-Sutcliffe (NSE) and bias percentage (Pbias) efficiency criteria were proposed by Moriasi et al. (2007).

After calibration and verification of the water regime quantification, the tabulated data of domestic and industrial discharge, as discharge point sources, were inserted in the model. From the data insertion, the model parameters calibration and the simulation of water quality scenarios were performed.

In this work, we opted to perform the analysis of the biochemical oxygen demand $\left(\mathrm{BOD}_{5,20}\right)$, and total phosphorus $\left(\mathrm{P}_{\text {total }}\right)$, total nitrogen $\left(\mathrm{N}_{\text {total }}\right)$ and thermotolerant coliforms $(\mathrm{CF})$, because they are relevant parameters in the framing process (Agência Nacional de Águas, 2013) and data availability.

For model calibration in relation to water quality parameters, data were monitored by companies with releases in the basin's rivers that perform non-systematic monitoring or government agencies, such as FAEMA (Municipal Environmental Foundation) in the city

Table 1. Physical-chemical characteristics of sanitation sewers.

\begin{tabular}{lcc}
\hline \multirow{2}{*}{ Parameter } & \multicolumn{2}{c}{ Contribution per capita } \\
\cline { 2 - 3 } & \multicolumn{2}{c}{ (g/hab.d) } \\
\cline { 2 - 3 } & Range & $\begin{array}{c}\text { Typical/ } \\
\text { Adopted }\end{array}$ \\
\hline Total solids & $120-220$ & 180 \\
Ultimate BOD & $60-90$ & 75 \\
Organic Nitrogen & $2.5-4.0$ & 3.5 \\
Ammonia & $3.5-6.0$ & 4.5 \\
Nitrite & 0 & 0.05 \\
Nitrate & $0.0-0.2$ & 0.01 \\
Organic Phosphorus & $0.2-1.0$ & 0.3 \\
Inorganic phosphorus & $0.25-1.5$ & 0.7 \\
\hline & Concentration (org/100 $\mathbf{m l})$ \\
\hline
\end{tabular}

\begin{tabular}{lcc}
\hline Thermotolerant coliforms (CF) & $10^{6}-10^{9}$ & $10^{6}-$ \\
\hline
\end{tabular}

Source: Adapted from Von Sperling (2005). of Blumenau that performs water quality monitoring in several localities of the city. The period from 2010 to 2017 was analysed.

The sediment, although not a parameter analysed in this study, had to be calibrated even without details, because it was noted that its adequacy improved the calibration of other parameters in the water quality model.

According to Moriasi et al. (2007), for monthly calibrations of nitrogen and phosphorus, performance for Pbias $< \pm 25 \%$ is considered very good, $\pm 25 \%<$ Pbias $<40 \%$ performance is considered good, $\pm 40 \%<$ Pbias $< \pm 70 \%$ satisfactory and for Pbias $> \pm 70 \%$ is unacceptable. However, Moriasi et al. (2007) points to the need to adjust these classifications when uncertainties are very low or very high, that is, uncertainties in data measurement should be considered to evaluate river basin models. According to the same author, graphical techniques provide a visual comparison of observed and simulated data, giving an overview on model performance. Both hydrograms and permanence curves are especially valuable for model evaluation.

Moriasi et al. (2007) also considers that in situations where there is no complete time series of monitoring, when only a few samples are available per year, the data may not be sufficient for analysis using the recommended statistics. In these situations, the frequency distributions comparison or percentiles may be more appropriate than the statistical guidelines.

According to Harmel et al. (2006), when calibration and evaluation data of the model are collected under difficult hydrological conditions, the uncertainty values can exceed $40 \%$ for flow and $150 \%$ to $400 \%$ for nutrients. Harmel et al.(2006) also mentioned that analysis of samples in low polluted environments with low pollutant concentrations are more sensitive to errors, and result in a high degree of uncertainty. Coelho et al. (2019) evaluated the uncertainties from monitoring water quality parameters in the Alto Iguaçu basin, and corroborated these analyses.

In this context, the quality model was calibrated according to performance indexes (Pbias) as indicated by Moriasi et al. (2007), together with observation of hydrographs and frequency distribution, admitting the uncertainties, and considering adverse factors for the model sensitivity analysis.

\section{Simulated scenarios}

The scenarios were simulated with focus on 4 water quality parameters $\left(\mathrm{BOD}_{5,20^{\circ} \mathrm{C}}, \mathrm{P}_{\text {total }}, \mathrm{N}_{\text {total }}\right.$ and $\left.\mathrm{CF}\right)$. The scenarios are:

- Current scenario, depicting the current basin situation. The simulation showed $35 \%$ efficiency for $\mathrm{BOD}_{5,20^{\circ} \mathrm{C}}$ and total phosphorus, $30 \%$ for total nitrogen and $90 \%$ for thermotolerant coliforms, considering that municipalities have primary treatment for domestic sewage, as recommended by Von Sperling (2005);

- Critical scenario, population projection for the year 2040 with 49 municipalities in the basin, representing efficiencies for water quality parameters equal to the current scenario;

- Acceptable scenario, similar to the critical scenario, but representing $60 \%$ efficiency for $\mathrm{BOD}_{5,20^{\circ} \mathrm{C}}$, total phosphorus and total nitrogen; 
- Recommended scenario, similar to the critical scenario, but representing $80 \%$ efficiency for $\mathrm{BOD}_{5,20^{\circ} \mathrm{C}}, 35 \%$ for total phosphorus, $70 \%$ for total nitrogen and $99 \%$ for thermotolerant coliforms.

The scenarios were simulated for reference flow $\left(\mathrm{Q}_{98 \%}\right)$, a frequency of $80 \%$ exceedance, mean and median, in order to evaluate the statistical index that best represents water quality parameters. Similarly, the scenarios for the gradual implementation of treatment systems were simulated, as recommended in the analysis of investments for implantation.

\section{Investments for the implementation of effluent treatment systems}

After elaborating the simulated scenarios with predictions on the implantation of effluent treatment systems, the cost effectiveness of the proposed scenario was calculated. Costs were calculated by the methodology adopted from the Atlas Sewage: Hydrological Watershed Depollution (Agência Nacional de Águas, 2017). This is a guide for municipalities and management agencies that encounter the need to analyse and expand the knowledge of sewage systems in all municipalities in the country. The guide presents suggestions for implementing actions in sewage collection and treatment, with the aim of qualifying the decision-making, guiding the actions of development and application of financial resources and the sustainable use of water resources (Agência Nacional de Águas, 2017).

Due to high investment value for municipalities, it was proposed that the domestic effluent treatment systems in the basin be implemented in a gradual way to allow the municipalities time for resource planning and execution.

Scenarios were generated, divided into 4 execution phases, to reach universalization in the basin: by 2025 , the effluent treatment system would have the capacity to serve $15 \%$ of the total basin population; by $2030,30 \%$; by $2035,50 \%$ and by 2040 , universal treatment would be achieved in the Itajai basin $(80 \%$ of the population served).

\section{RESULTS AND DISCUSSION}

The SWAT model was calibrated and validated for hydrological regime quantification and for each water quality parameter $\left(\mathrm{BOD}_{5,20^{\circ} \mathrm{C}}, \mathrm{P}_{\text {total }}, \mathrm{N}_{\text {total }}\right.$ and $\left.\mathrm{CF}\right)$.

\section{Calibration and validation of the water regime quantification}

The calibration and validation of the hydrological model resulted in the NSE equal to 0.77 and Pbias equivalent to $1.0 \%$ for the Blumenau fluviometric station. The hydrographs are presented in Figure 3. The NSE and Pbias of the other stations

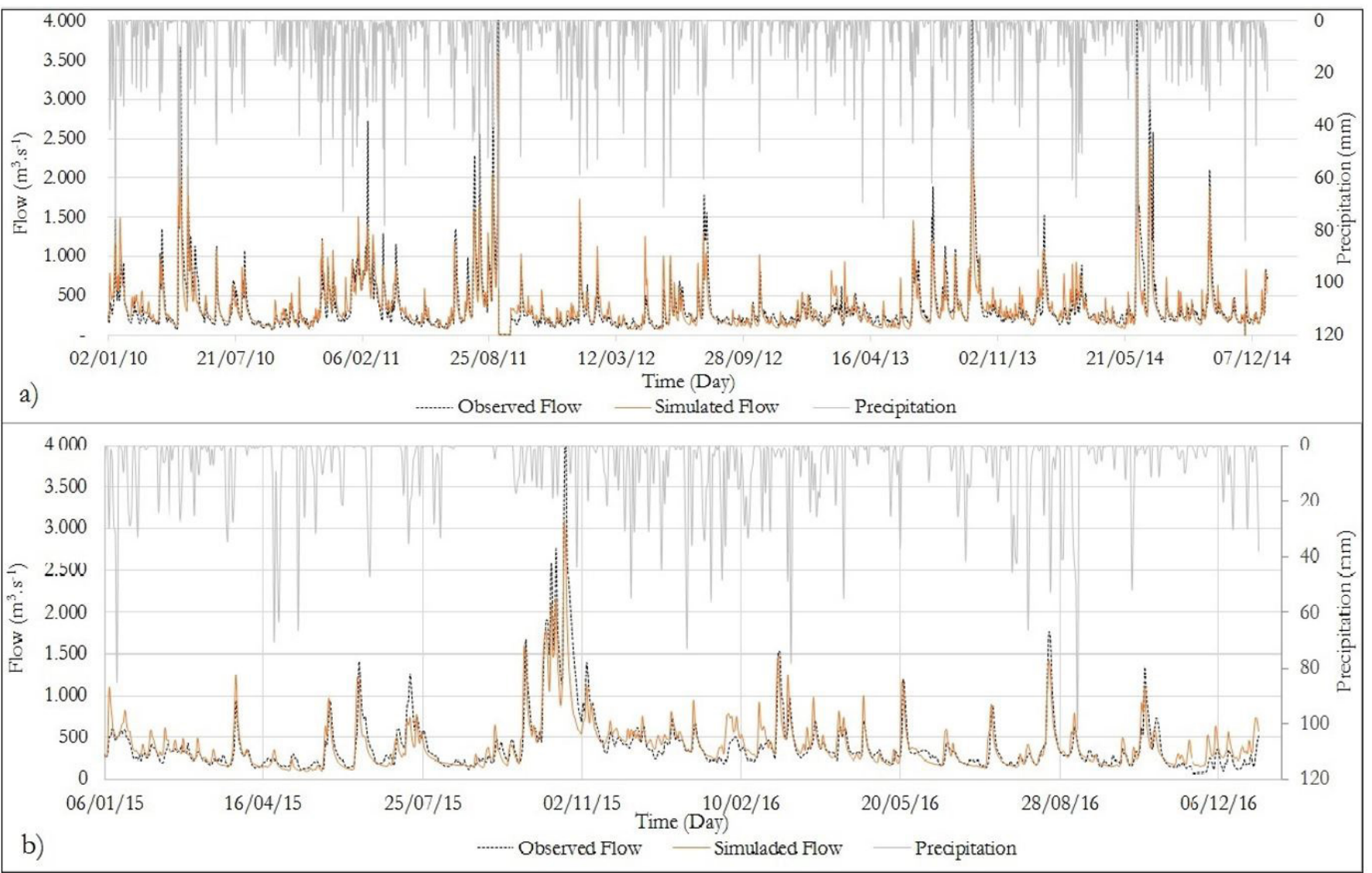

Figure 3. Hydrograph of calibration and validation for Blumenau fluviometric station (a) calibration period 2010-2014; (b) validation period 2015-2016. 
are shown in Table 2. According to Moriasi et al. (2007) and from observations in the hydrographs, calibration results range from very good to satisfactory.

Fluviometric stations, such as Salseiro and Ibirama, presented unsatisfactory NSE values for the calibration period. Nevertheless, the Pbias (an index that indicates the evaluation of measurement uncertainties) was reached, demonstrating good model calibration and validation. This incompatibility between indexes may be caused by flow regularization of the flood containment dams near these fluviometric stations. This may explain why the NSE, an index that evaluates the flow peaks, is unsatisfactory, and the Pbias, which evaluates the residual mass, is in good standing.

In general, the results reflected good calibration and validation of the model, allowing the generation of basin management scenarios.

The study's main objective is the simulation of water quality scenarios. Water quality scenarios may influence low flows. In order to better adjust for drought periods, the calibrations were evaluated according to the permanence curves, which assign a probability level of exceedance to a given event (Cunha et al., 2011). Moreover, permanence curves prioritise the similarities between observed flow and flow simulated in the reference, that is, in the $98 \%$ frequency for Santa Catarina (Santa Catarina, 2008) presented in Figure 4.

\section{Water quality calibration}

The lack of monitoring standardisation was the greatest difficulty encountered during calibration of the water quality model, among others. In general, monitoring is not thought to assess water quality, but to limit inappropriate water disposal. Therefore, monitoring without the necessary parameters for water quality analysis is constant. There is also no standardised periodicity of available data. Some organizations have a great deal of data available, while others have only 1 or 2 collections and analyses during the study period. Another factor observed in the monitoring data of different companies is that upstream $\mathrm{BOD}_{5,20^{\circ} \mathrm{C}}$

Table 2. Nash-Sutcliffe Coefficient (NSE) and Bias Percentage (Pbias) of the 11 (eleven) fluviometric stations calibrated and validated in the research.

\begin{tabular}{|c|c|c|c|c|}
\hline \multirow{2}{*}{$\begin{array}{l}\text { Fluviometric } \\
\text { Station (Code) }\end{array}$} & \multicolumn{2}{|c|}{$\begin{array}{l}\text { Calibration } \\
(2010-2014)\end{array}$} & \multicolumn{2}{|c|}{$\begin{array}{l}\text { Validation } \\
(2015-2016)\end{array}$} \\
\hline & NSE & $\begin{array}{c}\text { Pbias } \\
(\%)\end{array}$ & NSE & $\begin{array}{c}\text { Pbias } \\
(\%)\end{array}$ \\
\hline Blumenau (83800002) & 0.77 & 1.0 & 0.79 & -1.0 \\
\hline Indaial $(83690000)$ & 0.82 & 2.8 & 0.80 & -10.0 \\
\hline Apiuna (83500000) & 0.70 & -4.4 & 0.69 & -15.7 \\
\hline Rio do Sul (83300000) & 0.74 & 13.5 & 0.75 & -2.7 \\
\hline Ibirama $(83440000)$ & 0.34 & -11.9 & 0.60 & -12.2 \\
\hline Ituporanga (83250000) & 0.62 & 18.9 & 0.67 & -12.0 \\
\hline Timbo $(83677000)$ & 0.62 & -9.9 & 0.75 & -4.4 \\
\hline Taio $(83050000)$ & 0.61 & 14.9 & 0.68 & 8.1 \\
\hline Brusque (83900000) & 0.68 & -0.7 & 0.66 & -21.8 \\
\hline Benedito $(83660000)$ & 0.54 & -8.0 & 0.63 & -23.6 \\
\hline Salseiro (83892990) & 0.41 & 9.2 & 0.57 & -5.5 \\
\hline
\end{tabular}

is higher than downstream $\mathrm{BOD}_{5,20^{\circ} \mathrm{C}}$ in company data on certain dates, demonstrating inconsistency in the data.

Analysing water quality calibration and comparing it with the calibration and validation of the hydrological regime reveals a great disparity in the readings of the simulated data in comparison to the observed data. In the quantity calibration, the constancy of the results in the same HRU is notable, whereas, in the quality calibration, the data are spatial, highly variable in the area incorporated by the HRU. This can cause dispersion in the results when comparing the observed results (punctual) and the simulated results (spatial).

All the aforementioned situations lead to a high degree of uncertainty about the results (Coelho et al., 2019; Girardi, 2019).

The calibration hydrographs for the HRU located in Brusque are shown in Figure 5. Analysing the HRU of Brusque, the Pbias was verified, resulting in $43.27 \%$ for $\mathrm{BOD}_{5,20^{\circ} \mathrm{C}},-4.11 \%$ for total phosphorus and $9.82 \%$ for thermotolerant coliforms (it was not possible to verify the Pbias for total nitrogen because there were no observed data for this parameter in this HRU). According to the performance criteria analysed by Moriasi et al. (2007), in this HRU very good calibration for total phosphorus can be assumed. For $\mathrm{BOD}_{5,20^{\circ} \mathrm{C}}$ and thermotolerant coliforms, performance criteria for Pbias were not found in the literature, but if analysed in a similar way to nitrogen and phosphorus, they can be deemed satisfactory.

For HRU upstream from Blumenau, Pbias values for $\mathrm{BOD}_{5,20^{\circ} \mathrm{C}}$, total phosphorus, total nitrogen and thermotolerant coliforms were: $85.09,12.43,39.71$ and $55.83 \%$, respectively. These results demonstrate very good calibration for total phosphorus, good for total nitrogen and satisfactory for thermotolerant coliforms. Considering the $\mathrm{BOD}_{5,20^{\circ} \mathrm{C}}$, and assuming the uncertainties highlighted by Moriasi et al. (2007) and Harmel et al. (2006), also considering the low values found for $\mathrm{BOD}_{5,20^{\circ} \mathrm{C}}$ in this HRU, characterising the environment as having low pollution, it can be inferred that the calibration result is acceptable.

With all the highlighted uncertainties and the low availability of observed water quality data, the Pbias and the visual comparison through the hydrographs indicate that the SWAT provided

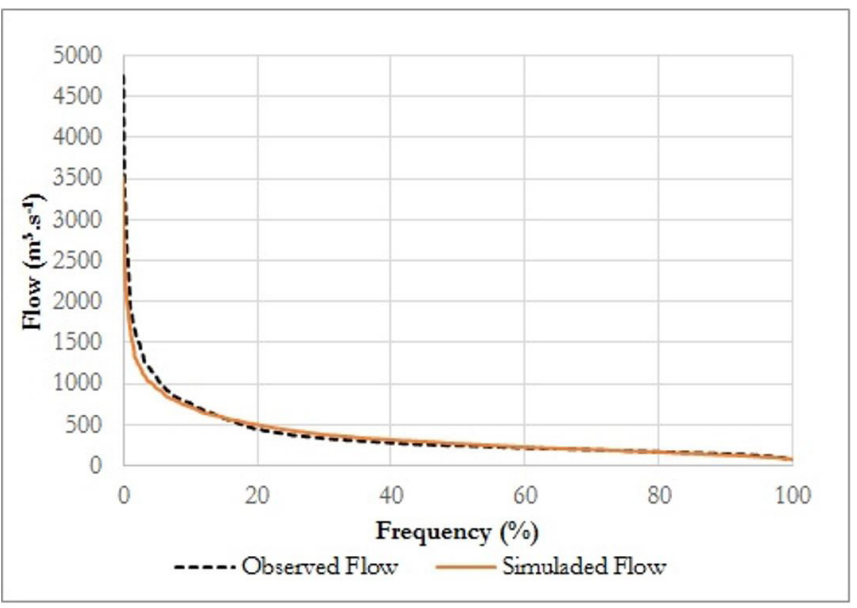

Figure 4. Flow permanence curves for Blumenau fluviometric station. 


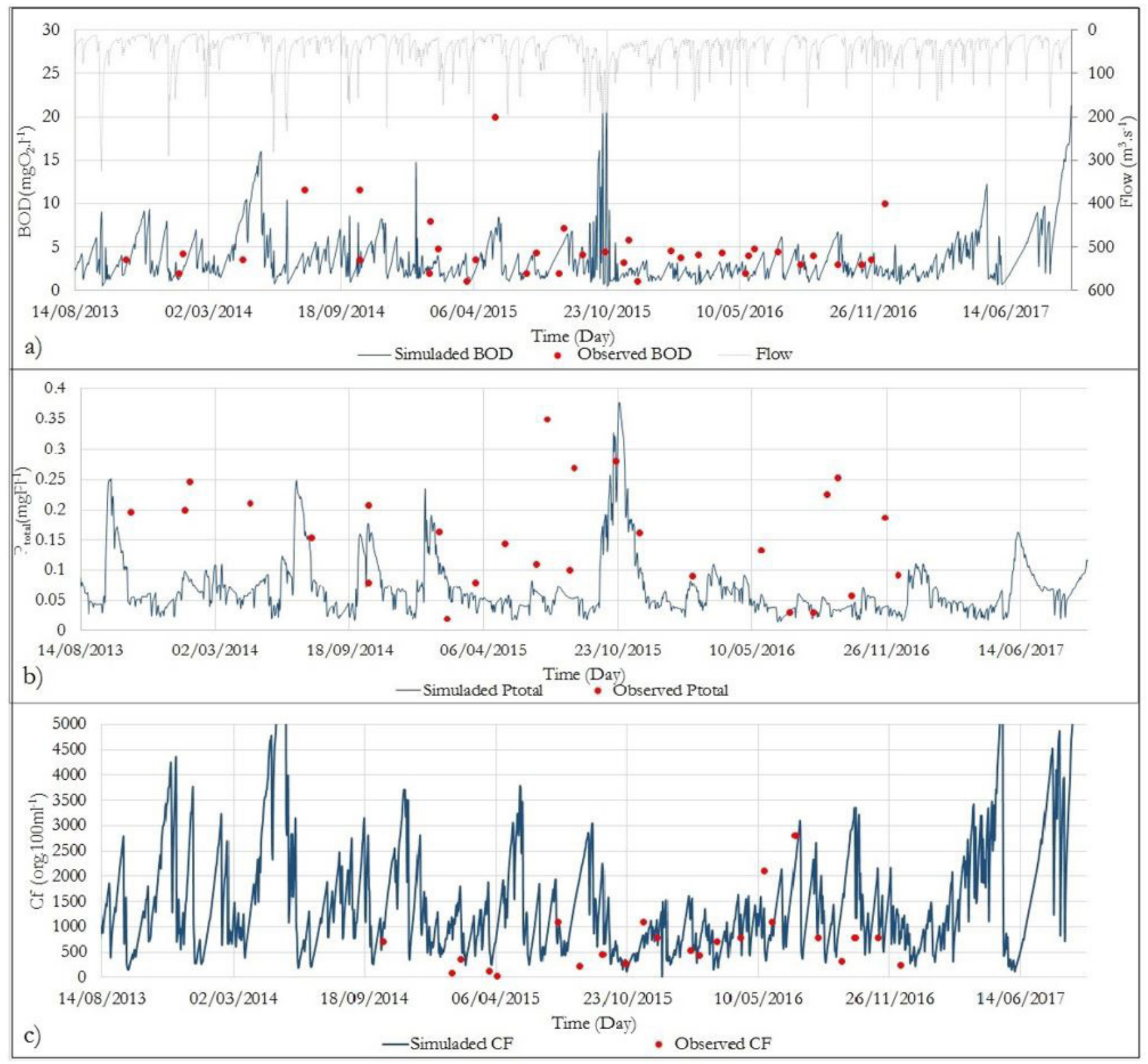

Figure 5. Daily comparison of (a) $\mathrm{BOD}_{5,20^{\circ} \mathrm{C}}$, (b) total phosphorus and (c) thermotolerant coliforms, simulated and observed for Sub basin/HRU 1323 (Brusque).

acceptable estimates in the simulation model. Although there were local divergences throughout the basin, the model captured seasonal variations of the water quality parameters when compared to the observed values.

Once the calibration for the analysed parameters is completed, the results may aid in the planning and implementation of water management guidelines.

\section{Concentrations permanence curves}

The concentration permanence curve represents the frequency that its values are not exceeded (Cunha et al., 2011). This study sought to analyse the water quality from pollutant concentrations, differing from other studies that analyse the quality of the resulting loads in the water courses (Lima et al., 2018; Fantin et al., 2017; Salla et al., 2013; Teodoro et al., 2013). This analysis is more complete by virtue of assigning the simultaneous flow to each analysed moment, bringing more reality to the presented results.

For that purpose, the concentration curves were constructed in each basin section. Two distinct HRUs (Blumenau and Brusque) were chosen to illustrate the results, shown in Figure 6. Permanence curves were used to verify the statistical index that best represents the pollutant concentrations in order to establish the basin classifications according to the uses desired.

The $80 \%$ exceedance frequency, the mean and the median for the 4 established scenarios (current, critical, acceptable and recommended) were compared in the permanence curves. 
As can be observed, the frequency of $80 \%$ always resulted the highest value among the statistical indices for $\mathrm{BOD}_{5,20^{\circ} \mathrm{C}}$ and thermotolerant coliforms. The exception occurs in the sections where the results are very low (a large number of zero or close to zero values), as in the case of the scenario recommended for the parameter $\mathrm{BOD}_{5,20^{\circ} \mathrm{C}}$, in the HRU assigned to Blumenau. However, this case should not be considered a problem, as the sections in which the results have minimum values are not expressive of class change. This shows that a frequency of $80 \%$ can be interpreted as the most significant value between the mean and the median to represent simulated values for each HRU.

Table 3 shows the frequency values of $80 \%$, mean, and median for the current, critical, acceptable and recommended scenarios.

\section{Reference flow}

According to resolution No. 357 (Brasil, 2005), to framework bodies of water by classes according to prevailing uses, classification should be established obeying the maximum values for the parameters in the reference flow conditions. The reference flow should be determined in the river basin plan. In Santa Catarina state, the reference flow was established as $\mathrm{Q}_{98 \%}$, that is, the flow that occurs 98\% of the time (Santa Catarina, 2008).

Therefore, in order to verify the statistical relationship that best represents pollutant concentrations in a hydrographic basin, the pollutant concentrations were compared at the $80 \%$ frequency, assumed to be the worst condition among the statistical indices analysed, with the concentrations found in the flow rate reference $\left(\mathrm{Q}_{98 \%}\right)$.

Table 4 summarizes the basin values as a whole in relation to the $80 \%$ frequency and reference flow $\left(\mathrm{Q}_{98 \%}\right)$. It can be seen that the reference flow represents the worst situation. However, the total phosphorus concentrations are $80 \%$ higher than those of $\mathrm{Q}_{98 \%}$. By analysing the simulated scenarios, the influence of diffuse source pollution on total phosphorus concentrations can be observed. This explains the reference flow values, which represent times with low surface runoff, presenting lower results than the $80 \%$ frequency.

The importance of the $80 \%$ frequency analysis beyond the reference flow is based on this. It is important that both be studied as a basis of the water resources plans.

Table 3. Frequency $80 \%$, mean, median and maximum values for the current, critical, acceptable and recommended scenarios for the $\mathrm{BOD}_{5,20^{\circ} \mathrm{C}}$ and thermotolerant coliforms parameters.

\begin{tabular}{|c|c|c|c|}
\hline \multirow{2}{*}{ Description } & $\mathrm{Fq} 80 \%$ & Mean & Median \\
\hline & \multicolumn{3}{|c|}{ BOD5,20 ${ }^{\circ}$ Blumenau (mgO2/1) } \\
\hline Current scenario & 1.36 & 1.20 & 0.84 \\
\hline Critical scenario & 1.96 & 1.61 & 1.23 \\
\hline Acceptable scenery & 1.34 & 1.18 & 0.82 \\
\hline \multirow[t]{2}{*}{ Recommended scenario } & 0.81 & 0.85 & 0.48 \\
\hline & \multicolumn{3}{|c|}{ BOD5,20 Brusque (mgO2/1) } \\
\hline Current scenario & 5.96 & 4.07 & 2.95 \\
\hline Critical scenario & 10.88 & 7.33 & 5.33 \\
\hline Acceptable scenery & 7.53 & 5.09 & 3.70 \\
\hline \multirow[t]{2}{*}{ Recommended scenario } & 4.78 & 3.29 & 2.38 \\
\hline & \multicolumn{3}{|c|}{ CF Blumenau (org/100ml) } \\
\hline Current scenario & 601.90 & 422.28 & 342.00 \\
\hline Critical scenario & 815.10 & 571.72 & 464.90 \\
\hline \multirow[t]{2}{*}{ Recommended scenario } & 82.59 & 57.91 & 47.10 \\
\hline & \multicolumn{3}{|c|}{ CF Brusque (org/100ml) } \\
\hline Current scenario & $2,686.00$ & $1,779.33$ & $1,261.00$ \\
\hline Critical Scenario & $4,267.00$ & $2,829.81$ & $2,016.50$ \\
\hline Recommended scenario & $1,005.00$ & 666.57 & 474.80 \\
\hline
\end{tabular}
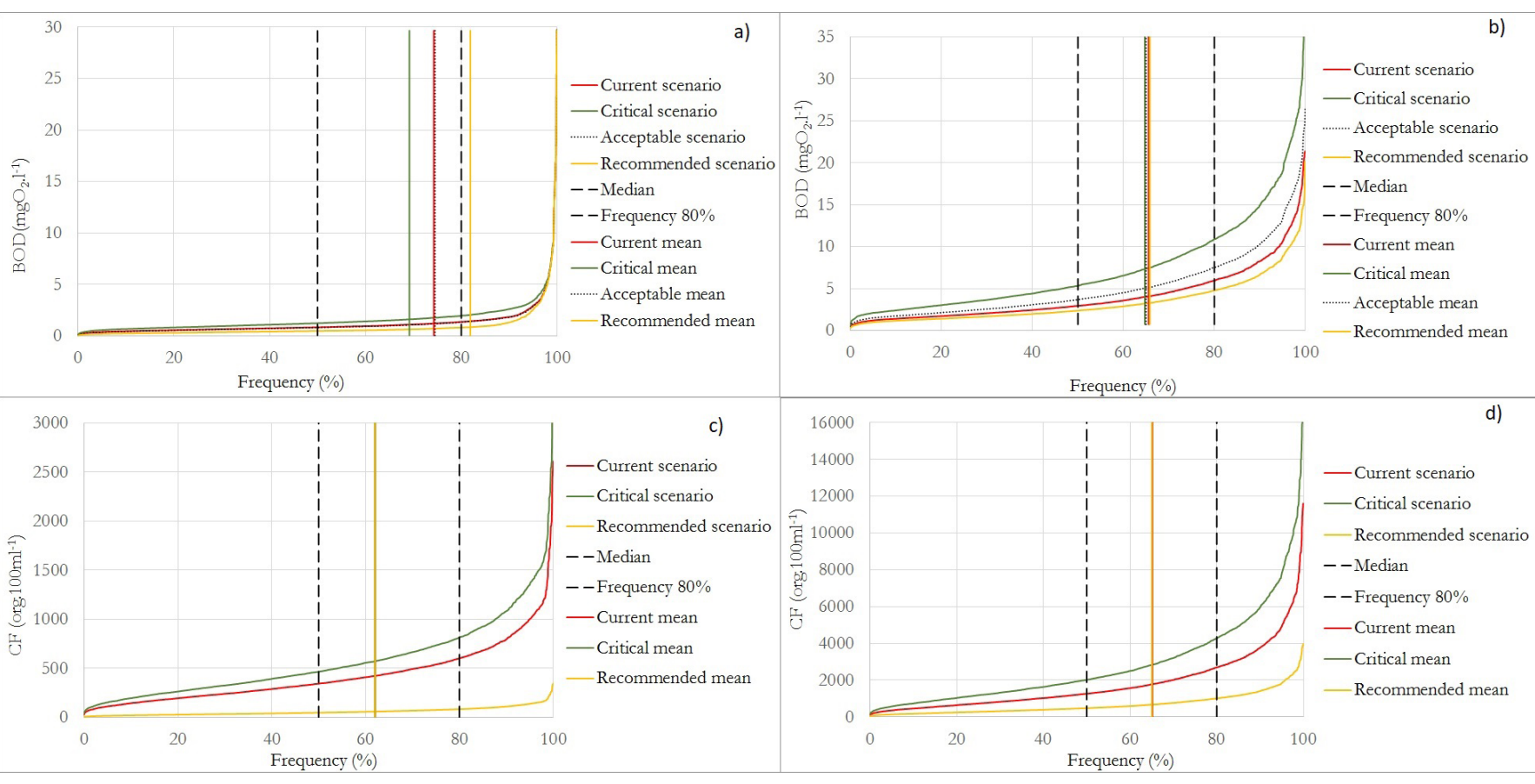

Figure 6. Concentration curves $(\mathrm{A}) \mathrm{BOD}_{5,20^{\circ} \mathrm{C}}$ (Blumenau) and $(\mathrm{B}) \mathrm{BOD}_{5,20^{\circ} \mathrm{C}}$ (Brusque); (C) Thermotolerant coliforms (Blumenau) and (D) Thermotolerant coliforms (Brusque), indicating mean, median and frequency $80 \%$ for the scenarios analysed. 
Table 4. Basin mean values for $\mathrm{BOD}_{5,20^{\circ} \mathrm{C}}$, thermotolerant coliforms $(\mathrm{CF})$, nitrates $\left(\mathrm{NO}_{3}\right)$, ammoniacal nitrogen $\left(\mathrm{NH}_{4}\right)$ and total phosphorus $\left(\mathrm{P}_{\text {total }}\right)$, according to the $80 \%$ frequency and reference flow.

\begin{tabular}{|c|c|c|}
\hline \multirow{3}{*}{ Scenarios description } & \multicolumn{2}{|c|}{ Basin mean } \\
\hline & $\mathrm{Fq} 80 \%$ & Q98 \\
\hline & \multicolumn{2}{|c|}{$\mathrm{BOD}_{5,20^{\circ} \mathrm{C}}(\mathrm{mgO} 2 / 1)$} \\
\hline Current scenario & 0.600 & 1.255 \\
\hline Critical scenario (2040) & 0.820 & 1.768 \\
\hline Acceptable scenery (2040) & 0.520 & 1.064 \\
\hline \multirow[t]{2}{*}{ Recommended scenario (2040) } & 0.340 & 0.638 \\
\hline & \multicolumn{2}{|c|}{ CF (org/100ml) } \\
\hline Current scenario & 245.310 & 644.228 \\
\hline Critical scenario (2040) & 322.860 & 826.749 \\
\hline \multirow[t]{2}{*}{ Recommended scenario (2040) } & 39.420 & 100.855 \\
\hline & \multicolumn{2}{|c|}{ NO3 (mgN/l) } \\
\hline Current scenario & 0.116 & 0.124 \\
\hline Critical scenario (2040) & 0.153 & 0.304 \\
\hline Acceptable scenery (2040) & 0.115 & \\
\hline \multirow[t]{2}{*}{ Recommended scenario (2040) } & 0.115 & 0.122 \\
\hline & \multicolumn{2}{|c|}{ NH4 (mgN/1) } \\
\hline Current scenario & 0.073 & 0.123 \\
\hline Critical scenario (2040) & 0.171 & 0.122 \\
\hline \multirow[t]{2}{*}{ Recommended scenario (2040) } & 0.071 & 0.115 \\
\hline & \multicolumn{2}{|c|}{ Ptotal (mgP/1) } \\
\hline Current scenario & 0.207 & 0.049 \\
\hline Critical scenario (2040) & 0.212 & 0.073 \\
\hline Acceptable scenery (2040) & 0.206 & 0.047 \\
\hline Recommended scenario (2040) & 0.210 & 0.058 \\
\hline
\end{tabular}

\section{Simulations of current and evolutionary scenarios}

Current and evolutionary scenarios were simulated as specified, classifying the rivers according to resolution No. 357 of the National Environmental Council (Brasil, 2005), for each water quality parameter: $\mathrm{BOD}_{5,20^{\circ} \mathrm{C}}, \mathrm{P}_{\text {total }}, \mathrm{NH}_{4}, \mathrm{NO}_{3}$ and $\mathrm{CF}$.

Comparing the current scenario with the critical scenario (Table 5) for the $\mathrm{BOD}_{5,20^{\circ} \mathrm{C}}$ parameter, in the reference flow there was an increase in degradation for the year 2040 by $40.9 \%$, changing the Itajai river from Blumenau to class 3, besides other local changes along the basin. Analysing the scenarios with $60 \%$ efficiency treatment systems, the problem is alleviated, with a $15.2 \%$ reduction of $\mathrm{BOD}_{5,20^{\circ} \mathrm{C}}$, but it still does not show enough improvement in quality in the places of greatest degradation. In the recommended scenario, in which there was a reduction of $49.2 \% \mathrm{BOD}_{5,20^{\circ} \mathrm{C}}$, a class change is noted, even in the most critical locations, proving to be the most efficient treatment system.

For the CF parameter, the current scenario already reflects great degradation of the main river basins. In the critical scenario, there is a pollution increase of $28.3 \%$ from CFs. Degradation of regions not previously affected is observed, with class alterations in localities like Timbo and Rio dos Cedros. With the implementation of the effluent treatment system with $99 \%$ efficiency for CFs, considerable improvement is observed, representing an $84.3 \%$ reduction for the reference flow.

Regarding $\mathrm{NO}_{3}$ and $\mathrm{NH}_{4}$ in the reference flow, the simulations show that there is a high $\mathrm{NO}_{3}$ increase in the critical
Table 5. Average percentage increases in the basin for $\mathrm{BOD}_{5,20^{\circ} \mathrm{C}}$, thermotolerant coliforms, ammoniacal nitrogen, nitrate and total phosphorus.

\begin{tabular}{|c|c|c|}
\hline \multirow{2}{*}{ Scenarios description } & \multicolumn{2}{|c|}{ Basin mean } \\
\hline & $\mathrm{Fq}_{80 \%}$ & $\mathrm{Q}_{98}$ \\
\hline & \multicolumn{2}{|c|}{$\mathrm{BOD}_{5,20^{\circ}}(\%)$} \\
\hline Current scenario & - & - \\
\hline Critical scenario (2040) & 36.7 & $40.9 \%$ \\
\hline Acceptable scenery (2040) & -13.3 & $-15.2 \%$ \\
\hline \multirow[t]{2}{*}{ Recommended scenario (2040) } & -43.3 & $-49.2 \%$ \\
\hline & \multicolumn{2}{|c|}{ CF (\%) } \\
\hline Current scenario & - & - \\
\hline Critical scenario (2040) & 31.6 & $28.3 \%$ \\
\hline \multirow[t]{2}{*}{ Recommended scenario (2040) } & -84.0 & $-84.3 \%$ \\
\hline & \multicolumn{2}{|c|}{$\mathrm{NO}_{3}(\%)$} \\
\hline Current scenario & - & - \\
\hline Critical scenario (2040) & 31.8 & $145.3 \%$ \\
\hline Acceptable scenery (2040) & -0.4 & \\
\hline \multirow[t]{2}{*}{ Recommended scenario (2040) } & -0.5 & $-1.25 \%$ \\
\hline & \multicolumn{2}{|c|}{$\mathrm{NH}_{4}(\%)$} \\
\hline Current scenario & - & - \\
\hline Critical scenario (2040) & 135.00 & -0.01 \\
\hline \multirow[t]{2}{*}{ Recommended scenario (2040) } & 0.00 & -6.50 \\
\hline & \multicolumn{2}{|c|}{$\mathbf{P}_{\text {total }}(\%)$} \\
\hline Current scenario & - & - \\
\hline Critical scenario (2040) & 2.70 & 49.00 \\
\hline Acceptable scenery (2040) & -0.20 & -4.32 \\
\hline Recommended scenario (2040) & 1.50 & 18.77 \\
\hline
\end{tabular}

scenario $(145.3 \%)$. This increase is not representative in the basin, as the concentrations parameter is very low in the basin as a whole, remaining in class 1 . The results for parameters associated with nitrogen for the $80 \%$ frequency indicate an increase of $135 \%$ for $\mathrm{NH}_{4}$ and no increase in the reference flow. The opposite occurs with $\mathrm{NO}_{3}$ - an increase of $145.3 \%$ in reference flow and $31.8 \%$ in the $80 \%$ frequency. These results corroborate the nitrogen cycle (Von Sperling, 2014) and evidence the influence of the diffuse nitrogen source.

Similarly, in the $\mathrm{P}_{\text {total }}$ simulation a large interference was observed by diffuse pollution sources. The results of the $80 \%$ frequency indicate high levels of the parameter already in the current scenario, showing little change when compared to the critical scenario. Observing the land use and occupation map, it can be seen that the areas where the highest values of this parameter are found constitute agricultural or pasture regions, leading to the conclusion that land use would be responsible for the increase in $\mathrm{P}_{\text {total }}$ in the basin water courses. The model uses values for phosphorus fraction in the plant and removal coefficient of this fraction. These values are not monitored in the region, that is, with no real results, and the standard data proposed by the manual model are adopted, requiring more complex studies to prove this assertion.

However, when analysing the parameter for reference flow, there is an increase of $49 \%$ in the critical scenario (Figure 7). This increase confirms the influence also by point source, a reduction of $4.32 \%$ being verified in the scenario that 


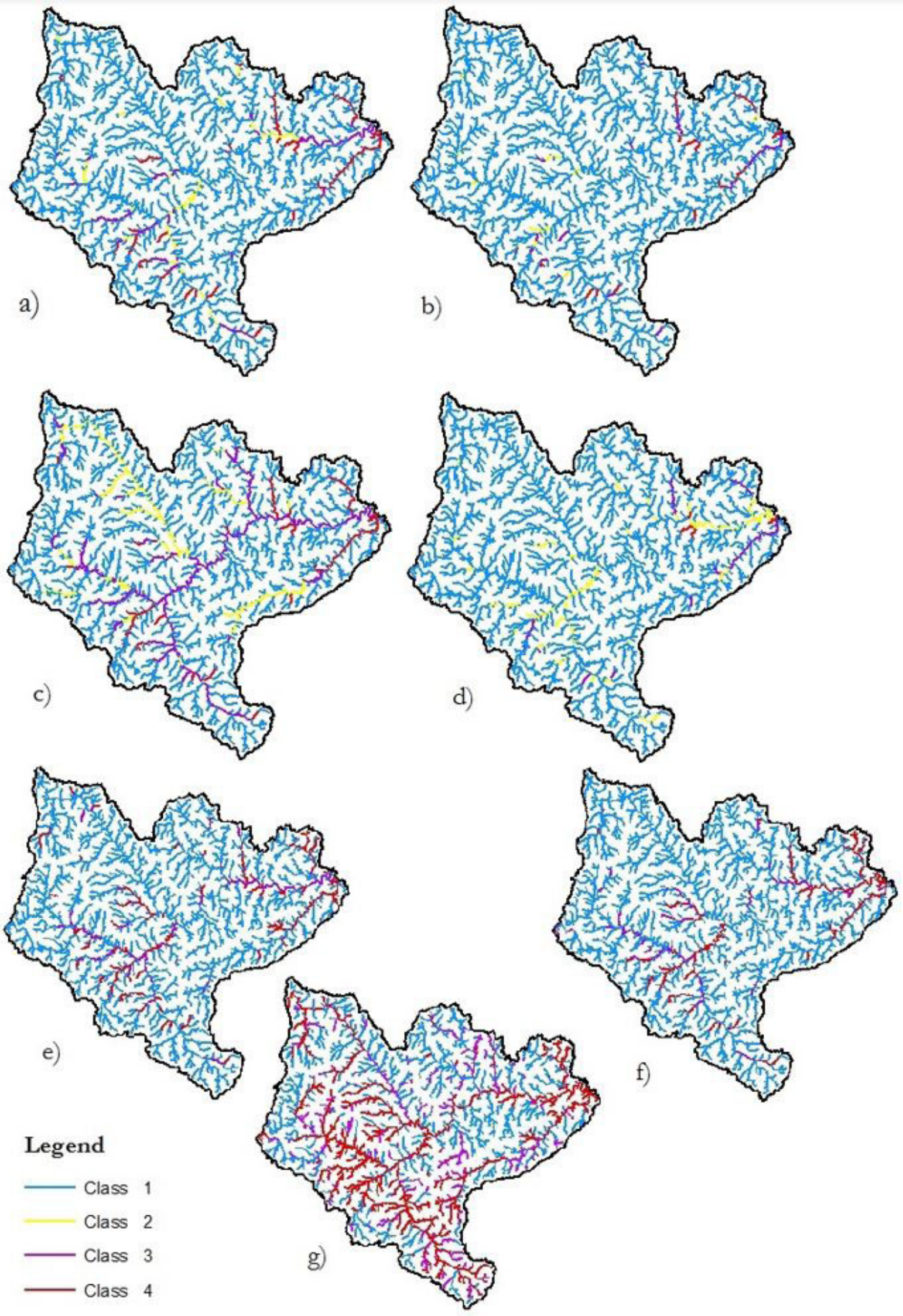

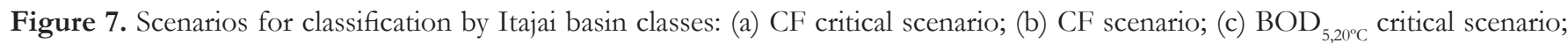
(d) $\mathrm{BOD}_{5,20^{\circ} \mathrm{C}}$ recommended scenario; (e) $\mathrm{P}_{\text {total }}$ critical scenario $\mathrm{Q}_{98 \%} ;$ (f) $\mathrm{P}_{\text {total }}$ recommended scenario $\mathrm{Q}_{98 \%}$; (g) $\mathrm{P}_{\text {total }}$ critical scenario and recommended $\mathrm{Fq}_{80 \%}$. 
represents $60 \%$ efficiency for $\mathrm{P}_{\text {total }}$ (acceptable scenario). For the recommended scenario, where efficiency of $35 \%$ was adopted for $\mathrm{P}_{\text {total }}$, there was less increase for the parameter than for the critical scenario. For the critical and recommended scenarios, there was an increase of $49 \%$ and $18.77 \%$, respectively, compared to the current scenario.

\section{Investments for the implementation of effluent treatment systems}

After analysing the simulation scenarios, a cost survey was carried out to implement universal treatment in the Itajai basin. The total investment for the treatment system implementation in the basin is $\mathrm{R} \$ 2,144,555,122.00$ (two billion, one hundred forty-four million, five hundred fifty-five thousand, one hundred twenty-two Brazilian reals), for treatment with 60-80\% efficiency, according to the methodology found in ANA (Agência Nacional de Águas, 2017).

Due to high disbursement by the municipalities in the short term, a gradual 4-step system implementation was proposed, as follows:

- by 2025, $15 \%$ (fifteen percent) of the basin population would benefit from effluents collection, transportation and treatment;

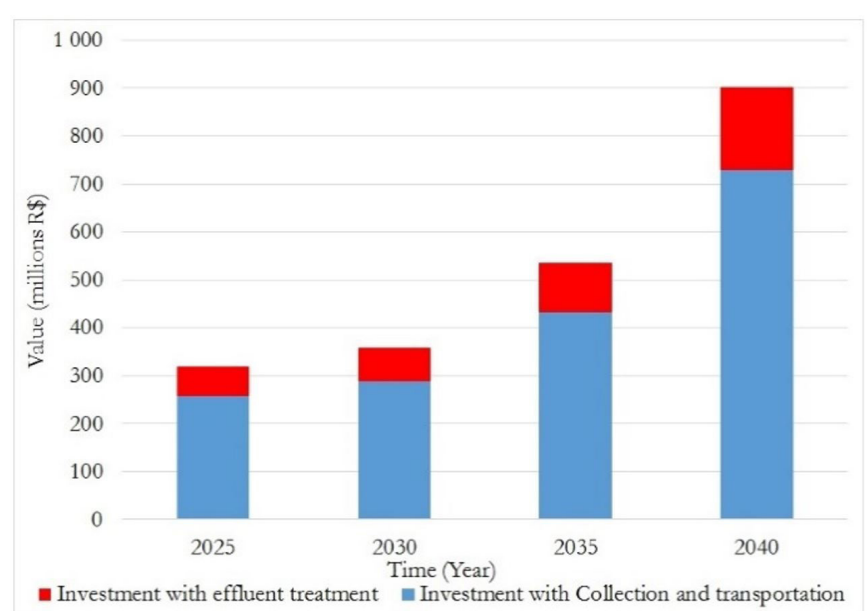

Figure 8. Proportional investment for implementation of sewage collection and treatment in the Itajai basin.
- by 2030 , the system would serve $30 \%$ of the basin population;

- by 2035 , the system would serve $50 \%$ of the population and;

- by 2040 , universal treatment ( $80 \%$ of the population) would be in effect in the Itajai basin.

Thus, the proportional costs would be generated for each system implementation phase, as shown in Figure 8, broken down by investments for sewage collection and transportation and effluent treatment investments.

\section{Simulation scenarios with proportional system deployment}

With the proposal to implement the proportional system, simulations were generated with scenarios for the years 2025, 2030, 2035 and 2040.

Scenarios were defined according to interpretation of the results presented in the study. Efficiencies of $80 \%$ for $\mathrm{BOD}_{5,20^{\circ} \mathrm{C}}$, $99 \%$ for $\mathrm{CF}, 50 \%$ for $\mathrm{P}_{\text {total }}$ and $70 \%$ for nitrogen were considered in the simulations, in view of the need to increase efficiency for $\mathrm{P}_{\text {total }}$. These efficiencies differ in simulations for the cities of Blumenau, Itajai, Brusque, Guabiruba, Pomerode, Luiz Alves and Agrolandia. These regions were identified as being in critical condition, requiring increased efficiency to meet framework goals. For these cities, $95 \%$ efficiency was proposed for $\mathrm{BOD}_{5,20^{\circ} \mathrm{C}}, 99.9 \%$ for $\mathrm{CF}, 50 \%$ for $\mathrm{P}_{\text {total }}$, and $70 \%$ for nitrogen.

It can be verified that if the effluent treatment system is implemented as suggested, there will be a reduction in the degradation of the basin water courses. Tables 6 and 7 show that for CF as early as 2025 , with $15 \%$ of the population served, there will be a reduction compared to the current scenario of $5.58 \%$. From 2030, with $30 \%$ of the population, the reduction will be $2.91 \%$ for $\mathrm{BOD}_{5.20^{\circ} \mathrm{C}}$ and $15.96 \%$ for CF. In 2040 , with $80 \%$ of the population (universal treatment), the reductions for $\mathrm{BOD}_{5,20^{\circ} \mathrm{C}}$ and CF will be 44.72 and 67.24\%, respectively. For $\mathrm{P}_{\text {total }}, \mathrm{NO}_{3}$ and $\mathrm{NH}_{4}$, because they are pollutants from diffuse sources, it is not possible to verify large reductions compared to the current scenario, but when compared to the critical scenario, the reductions are quite considerable.

Comparing the recommended scenario (the simulation to serve all the population projected for 2040) with the universal treatment condition $(80 \%$ of population attended), a reduction of efficiency is observed, but without complications for the basin.

Table 6. Basin mean values for $\mathrm{BOD}_{5,20^{\circ} \mathrm{C}}$ thermotolerant coliforms, ammoniacal nitrogen, nitrate and total phosphorus for the years 2025, 2030, 2035 and 2040, considering critical scenarios and scenarios with treatment by percentage of population served.

Basin mean for $\mathbf{Q}_{98 \%}$

\begin{tabular}{|c|c|c|c|c|c|c|c|c|c|}
\hline & \multirow{2}{*}{ Current } & \multicolumn{4}{|c|}{ Critical scenarios } & \multicolumn{4}{|c|}{ Scenario with effluent treatment system } \\
\hline & & 2025 & 2030 & 2035 & 2040 & $2025-15 \%$ & $2030-30 \%$ & $2035-50 \%$ & $2040-80 \%$ \\
\hline $\mathrm{BOD}_{5.20^{\circ} \mathrm{C}}$ & 1.255 & 1.471 & 1.574 & 1.643 & 1.768 & 1.273 & 1.218 & 1.026 & 0.694 \\
\hline CF & 644.228 & 717.916 & 754.499 & 782.293 & 826.749 & 608.270 & 541.433 & 435.029 & 211.070 \\
\hline $\mathbf{P}_{\text {total }}$ & 0.049 & 0.054 & 0.056 & 0.058 & 0.073 & 0.053 & 0.054 & 0.055 & 0.053 \\
\hline $\mathrm{NO}_{3}$ & 0.12405 & 0.1238 & 0.1239 & 0.12408 & 0.1217 & 0.1235 & 0.1233 & 0.1231 & 0.1225 \\
\hline $\mathbf{N H}_{4}$ & 0.1233 & 0.144 & 0.152 & 0.161 & 0.304 & 0.136 & 0.134 & 0.131 & 0.115 \\
\hline $\mathbf{N}_{\text {total }}$ & 0.705 & 0.565 & 0.582 & 0.753 & 0.887 & 0.686 & 0.544 & 0.682 & 0.650 \\
\hline
\end{tabular}


Table 7. Average percentage increase of $\mathrm{BOD}_{5,20^{\circ} \mathrm{C}}$, thermotolerant coliforms, ammoniacal nitrogen, nitrate and total phosphorus in the basin for the years 2025, 2030, 2035 and 2040, considering critical scenarios and scenarios with treatment by percentage of population served.

\begin{tabular}{|c|c|c|c|c|c|c|c|c|}
\hline \multicolumn{9}{|c|}{ Basin mean for $\mathbf{Q}_{98 \%}$} \\
\hline & \multicolumn{4}{|c|}{ Critical scenario } & \multicolumn{4}{|c|}{ Scenario with effluent treatment system } \\
\hline & 2025 & 2030 & 2035 & 2040 & $2025-15 \%$ & $2030-30 \%$ & $2035-50 \%$ & $2040-80 \%$ \\
\hline $\mathrm{BOD}_{5,20^{\circ} \mathrm{C}}$ & $17.25 \%$ & $25.42 \%$ & $30.96 \%$ & $40.89 \%$ & $1.43 \%$ & $-2.91 \%$ & $-18.24 \%$ & $-44.72 \%$ \\
\hline CF & $11.44 \%$ & $17.12 \%$ & $21.43 \%$ & $28.33 \%$ & $-5.58 \%$ & $-15.96 \%$ & $-32.47 \%$ & $-67.24 \%$ \\
\hline $\mathbf{P}_{\text {total }}$ & $10.81 \%$ & $14.48 \%$ & $17.81 \%$ & $49.08 \%$ & $8.06 \%$ & $10.50 \%$ & $12.08 \%$ & $9.34 \%$ \\
\hline $\mathrm{NO}_{3}$ & $-0.22 \%$ & $-0.11 \%$ & $0.02 \%$ & $-1.88 \%$ & $-0.44 \%$ & $-0.60 \%$ & $-0.75 \%$ & $-1.25 \%$ \\
\hline $\mathrm{NH}_{4}^{3}$ & $16.72 \%$ & $23.08 \%$ & $30.24 \%$ & $146.75 \%$ & $10.17 \%$ & $8.33 \%$ & $6.13 \%$ & $-6.55 \%$ \\
\hline $\mathbf{N}_{\text {total }}$ & $-19.90 \%$ & $-17.49 \%$ & $6.79 \%$ & $25.89 \%$ & $-2.64 \%$ & $-22.88 \%$ & $-3.32 \%$ & $-7.78 \%$ \\
\hline
\end{tabular}

\section{CONCLUSIONS}

Results show that the SWAT hydrological model allows simulating water quality evolution for land use and occupation situations in the Itajai river basin in order to support decision-making in the process of water resource management. Flows series and concentrations compatible with the water use management in the basin were generated for homogeneous areas.

The study included analyses verifying the statistical index that best represents the situation of the water courses. From the results, it was possible to verify that for the parameters in which water quality degradation is attributed to the discharge of domestic and industrial effluents, the index that represents the worst situation is that observed in the reference flow conditions. However, when analysing parameters in which this degradation is attributed to diffuse sources, it is necessary to consider the frequency of $80 \%$. In this context, the importance of permanence curve evaluation in water quality analysis is verified, as integration of observations of the conditions of reference flow and exceedance frequency of $80 \%$ were required, in order to reach more complete results for decision-making and water resources management.

The methodology developed to evaluate implementation of effluent treatment systems by the efficiency of pollutant removal, through modelling with distributed spatial discretization, enabled a complex and realistic analysis of the pollutants' behaviour in the aquatic environment, as it attributed the simultaneous flow to the instant analysed. The basin discretization in small contribution areas provides greater accuracy of the model. The daily and distributed results in the basin provide localized information, according to the basin ortho coding, and supporting the decision-making.

Therefore, this study can contribute to the process corresponding to implantation of the surface water courses framework in the Itajai basin, and also serve as a generic model for other localities.

\section{ACKNOWLEDGEMENTS}

The authors would like to thank FAPESC (Granting Term 2016TR2525) for the financial support of the "Itajai River Basin Framework Enhancement Program" and CNPq (process 131215/2017-5 and 309980/2017-8) for the master's scholarship and productivity, respectively.

\section{REFERENCES}

Agência Nacional de Águas - ANA. (2013). Cadernos de capacitação em recursos hidricos: planos de recursos hidricos e enquadramento dos corpos de água. Brasília: ANA.

Agência Nacional de Águas - ANA. (2017). Atlas esgotos: despoluição de bacias hidrográficas. Brasília: ANA. Retrieved in 2019, January 13, from http://www.snirh.gov.br/portal/snirh/snirh-1/atlas-esgotos

Agência Nacional de Águas - ANA. (2018). Hidroweb (Séries Históricas). Brasília: ANA. Retrieved in 2019, January 13, from http:/ / www.snirh.gov.br/hidroweb/publico/medicoes_historicas_abas.jsf

Antunes, R. B., \& Constante, V. T. (2016). Hidrografia. In I. O. Rocha (Org.), Atlas geográfico de Santa Catarina. Diversidade da natureza (Fascículo 2, Cap. 6). Florianópolis: Editora Udesc.

Babbar, R. (2014). Pollution risk assessment based on QUAL2EUNCAS simulations of a tropical river in Northern India. Environmental Monitoring and Assessment, 186(10), 6771-6787. PMid:24990347. http://dx.doi.org/10.1007/s10661-014-3888-1.

Baffaut, C., Dabney, S. M., Smolen, M. D., Youssef, M. A., Bonta, J. V., \& Chu, M. L., Guzman, J. A., Shedekar, V. S., Jha, M. K., \& Arnold, J. G. (2015). Hydrologic and water quality modeling: spatial and temporal considerations. Transactions of the ASABE, 58(6), 1661-1680. http://dx.doi.org/10.13031/trans.58.10714.

Batista, D. F., \& Cabral, J. B. P. (2017). Modelos matemáticos para avaliação do índice de qualidade de água: uma revisão. Acta Geográfica, 11(25), 111-136.

Bitencourt, C. C. A. (2018). Integração de análise estatística multivariada e geoprocessamento: aplicação para estudos de enquadramento de corpos d'água (Dissertação de mestrado). Pós-graduação em Engenharia de Recursos Hídricos e Ambiental, Universidade Federal do Paraná, Curitiba.

Brasil. (1997 janeiro). Lei n ${ }^{\circ}$ 9.433, de 8 de janeiro de 1997. Institui a Política Nacional de Recursos Hídricos, cria o Sistema Nacional de Gerenciamento de Recursos Hídricos, regulamenta o inciso XIX do art. 21 da Constituição Federal e altera o art. $1^{\circ}$ da Lei $\mathrm{n}^{\circ}$ 8.001, de 13 de março de 1990, que modificou a Lei n ${ }^{\circ} 7.990$, de 28 de dezembro de 1989. Diário Oficial [da] República Federativa do Brasil, Brasília. 
Brasil. (2005 março). Resolução CONAMA No 357, de 17 de março de 2005. Dispõe sobre a classificação dos corpos de água e diretrizes ambientais para o seu enquadramento, bem como estabelece as condições e padrões de lançamento de efluentes, e dá outras providências. Diário Oficial [da] República Federativa do Brasil, Brasília. p. 58-63.

Bressiani, D. A., Gassman, P. W., Fernandes, J. G., Garbossa, L. H. P., Srinivasan, R., Bonumá, N. B., \& Mendiondo, E. M. (2015). Review of soil and water assessment tool (SWAT) applications in Brazil: challenges and prospects. International Journal of Agricultural and Biological Engineering, 8(3), 9.

Brites, A. P. Z. (2010). Enquadramento dos corpos de água através de metas progressivas: probabilidade de ocorrência e custos de despoluição bídrica (Tese de doutorado). Escola Politécnica, Universidade de São Paulo, São Paulo.

Calmon, A. P. S., Souza, J. C., Reis, J. A. T., \& Mendonça, A. S. F. (2016). Uso combinado de curvas de permanência de qualidade e modelagem da autodepuração como ferramenta para suporte ao processo de enquadramento de cursos d'água superficiais. $R B R H$ - Revista Brasileira de Recursos Hídricos, 21(1), 118-133. http:/ /dx.doi. org/10.21168/rbrh.v21n1.p118-133.

Coelho, M., Fernandes, C. V. S., \& Detzel, D. H. M. (2019). Uncertainty analysis in the detection of trends, cycles, and shifts in water resources time series. Water Resources Management, 33(8), 1-16. http://dx.doi.org/10.1007/s11269-019-02210-1.

Cunha, D. G., Dodds, W. K., \& Carmo Calijuri, Md. (2011). Defining nutrient and biochemical oxygen demand baselines for tropical rivers and streams in São Paulo State (Brazil): a comparison between reference and impacted sites. Environmental Management, 48(5), 945-956. PMid:21858554. http://dx.doi.org/10.1007/ s00267-011-9739-8.

Fantin, L. L. D., Reis, J. A. T., \& Mendonça, A. S. F. (2017). Proposal of a methodology for pre-selection of sewage treatment systems within watersheds. RBRH: Revista Brasileira de Recursos Hidricos, 22, e12. https://doi.org/10.1590/2318-0331.011716079.

Ferreira, D. M., Fernandes, C. V. S., \& Kaviski, E. (2016). Curvas de permanência de qualidade da água como subsídio para o enquadramento de corpos d'água a partir de modelagem matemática em regime não permanente. RBRH - Revista Brasileira de Recursos Hídricos, 21(3), 479-492. http:/ /dx.doi.org/10.1590/23180331.011615143.

Geoambiente Sensoriamento Remoto Ltda. (2008). Projeto de Proteção da Mata Atlântica em Santa Catarina (PPMA/SC). (Relatório Técnico do Mapeamento Temático Geral do Estado de Santa Catarina, 90 p.). São José dos Campos: Geoambiente.

Girardi, R. (2019). Monitoramento não sistemático da qualidade de água e seu potencial para utilização na gestão de recursos hídricos (Tese de doutorado). Pós-graduação em Engenharia Ambiental, Centro de Ciências Tecnológicas, Fundação Universidade Regional de Blumenau, Blumenau.
Harmel, R. D., Cooper, R. J., Slade, R. M., Haney, R. L., \& Arnold, J. G. (2006). Cumulative uncertainty in measured streamflow and water quality data for small watersheds. Transactions of the ASABE, 49(3), 689-701. http://dx.doi.org/10.13031/2013.20488.

Instituto Brasileiro de Geografia e Estatística - IBGE. (2017). Sinopse do Censo Demográfico 2010: Santa Catarina. Rio de Janeiro: IBGE. Retrieved in 2017, November 13, from https:/ / censo2010. ibge.gov.br/sinopse/index.php?uf $=42 \&$ dados $=29$

Instituto Nacional de Meteorologia - INMET. (2018). Instituto Nacional de Meteorologia: dados históricos. Brasília: INMET. Retrieved in 2018, March 10, from http:/ / www.inmet.gov.br/portal/index. php?r=bdmep/bdmep.

Korf, E. P., Casagrande, R. L., Bedin, M. F. M., \& Vargas, G. D. L. P. (2017). Monitoramento e calibração de modelo de qualidade das águas do rio passo fundo. Revista de Ciências Ambientais, 11(1), 19-32. http://dx.doi.org/10.18316/rca.v11i1.2767.

Lima, B. P., Mamede, G. L., \& Lima Neto, I. E. (2018). Monitoring and modeling of water quality in a semiarid watershed. Engenharia Sanitaria e Ambiental, 23(1), 125-135. http://dx.doi.org/10.1590/ s1413-41522018167115.

Mello, C. D., Viola, M. R., Norton, L. D., Silva, A. M., \& Weimar, F. A. (2008). Development and application of a simple hydrologic model simulation for a Brazilian headwater basin. Catena, 75(3), 235-247. http://dx.doi.org/10.1016/j.catena.2008.07.002.

Moriasi, D. N., Arnold, J. G., Van Liew, M. W., Bingner, R. L., Harmel, R. D., \& Veith, T. L. (2007). Model evaluation guidelines for systematic quantification of accuracy in watershed simulations. Transactions of the ASABE, 50(3), 885-900. http://dx.doi. org/10.13031/2013.23153.

Neitsch, S. L., Arnold, J. G., Kiniry, J. R., \& Williams, J. R. (2011). Soil and water assessment tool theoretical documentation version 2009. Texas: Texas Water Resources Institute.

Noh, J., Choi, H., \& Lee, S. (2015). Water quality projection in the Geum River basin in Korea to support integrated basin-wide water resources management. Environmental Earth Sciences, 73(4), 1745-1756. http://dx.doi.org/10.1007/s12665-014-3524-y.

Pinheiro, A., Faht, G., Girardi, R., Pinheiro, I. G., \& Beilfuss, B. H. (2017). Sistema de apoio a gestão da qualidade da água no estado de Santa Catarina, Brasil. In: Simpósio de Hidráulica e Recursos Hidricos dos Países de Lingua Portuguesa. Porto: FENAREG. Retrieved in 2017, December 5, from https://www.researchgate. net/publication/319762707_Sistema_de_apoio_a_gestao_da_ qualidade_da_agua_no_estado_de_Santa_Catarina_Brasil

Salla, M. R., Pereira, C. E., Alamy Filho, J. E., Paula, L. D., \& Pinheiro, A. M. (2013). Estudo da autodepuração do Rio Jordão, localizado na bacia hidrográfica do Rio Dourados. Engenharia Sanitaria e Ambiental, 18(2), 105-114. http://dx.doi.org/10.1590/ S1413-41522013000200002. 
Santa Catarina. (2008 junho). Portaria SDS no 36, de 29 de julho de 2008. Estabelece os critérios de natureza técnica para outorga de direito de uso de recursos hídricos para captação de água superficial, em rios de domínio do Estado de Santa Catarina e dá outras providências. Diário Oficial do Estado, Florianópolis.

Santa Catarina. Secretaria de Estado do Desenvolvimento Econômico e Sustentável. (2017a). Recursos hídricos de Santa Catarina. Florianópolis: Sistema de Informações de Recursos Hídricos do Estado de Santa Catarina. Retrieved in 2017, June 5, from http:/ / sigsc.sds.sc.gov.br/download/

Santa Catarina. Centro de Informações de Recursos Ambientais e de Hidrometeorologia de Santa Catarina - CIRAM. Empresa de Pesquisa Agropecuária e Extensão Rural de Santa Catarina - EPAGRI. (2017b). Mapas digitais de Santa Catarina. Retrieved in 2017, June 5, from http:/ / ciram.epagri.sc.gov.br/mapoteca/

Seo, M., Jaber, F., Srinivasan, R., \& Jeong, J. (2017). Evaluating the impact of low impact development (LID) practices on water quantity and quality under different development designs using SWAT. Water (Basel), 9(3), 193. http:/ / dx.doi.org/10.3390/w9030193.

Silva, F. J. L. (2016). Um framework para o desenvolvimento de sistemas de apoio à decisão para a gestão de recursos hídricos (Tese de doutorado). Universidade Federal do Rio de Janeiro, Rio de Janeiro.

Sistema Nacional de Informações sobre Saneamento - SNIS. (2017). SNIS - Série Histórica. Brasília: SNIS. Retrieved in 2017, November 13, from http://app4.cidades.gov.br/serieHistorica/\#

Teodoro, A., Ide, C. N., Ribeiro, M. L., Broch, S. A. O., \& Silva, J. B. (2013). Implementation of the concept capacity for dilution of effluents in the water quality model QUAL-UFMG: a case study in Taquarizinho River (MS). Engenharia Sanitaria e Ambiental, 18(3), 275-288. http://dx.doi.org/10.1590/S1413-41522013000300010.
Venzon, P. T., Pinheiro, A., \& Kaufmann, V. (2018). Hydrological simulation uncertainties in small basins through the SWAT model. RBRH - Revista Brasileira de Recursos Hídricos, 23, e49. http:/ / dx.doi. org/10.1590/2318-0331.231820180014.

Von Sperling, M. (2005). Introducão à qualidade das águas e ao tratamento de esgotos (3. ed.). Belo Horizonte: Editora UFMG.

Von Sperling, M. (2014). Estudos e modelagem da qualidade da água (2. ed.). Belo Horizonte: Editora UFMG.

Wu, C., \& Fan, C. (2017). Integrated application of river water quality modelling and cost-benefit analysis to optimize the environmental economical value based on various aquatic waste load reduction strategies. EGU General Assembly, 19, EGU2017-EGU6435.

\section{Authors contributions}

Kelen Mannes Knaesel: Contributed with the elaboration of the study central idea. Carried out the simulations, analysis and discussion of the results, preparation of the paper including writing, drawing of figures and tables and bibliographic review.

Adilson Pinheiro: Contributed with the elaboration of the study central idea, simulations, analysis of the results and writing of the paper.

Pedro Thiago Venzon: Contributed with consistent data flow, macro development (automation of tasks) to reading the results of the simulations and paper preparation.

Vander Kaufmann: Contributed with central idea for model development in SWAT. 